\title{
TAPODI ZsUZsA*
}

\section{IDENTITÁSKONSTRUKCIÓK HÁROM DÉLSZLÁV REGÉNYBEN (IVO ANDRIĆ: OMÉR PASA, MILORAD PAVIĆ: KAZÁR SZÓTÁR, JOŽE HRADIL: KÉPEK ARC NÉLKÜL)}

\author{
Kulcsszavak: délszláv irodalom, birodalmak, határok, multikulturalitás, identitás
}

A délszláv nyelvváltozatokban íródott regények keletkezését 35 év választja el egymástól, melyek során nemcsak a szocialista rendszer bomlott fel, hanem a volt Jugoszláv Szocialista Köztársaság is alkotó elemeire hullott. Mindhárom mú egy-egy soknemzetiségú, sokkultúrájú birodalom kereteiben élő népesség életkörülményeinek változását, és a történelmi sorsfordulók hatására alakuló identitásváltozatokat vizsgálja.

Ivo Andrić (1892-1975) Nobel-díjas horvát származású szerb-bosnyák író utolsó, töredékben maradt történelmi regénye, az Omerpasa Latas 1977-ben, posztumusz látott napvilágot. Andrić boszniai katolikus család sarjaként műveinek csak töredékét írta kifejezetten horvátul, azt is írói pályafutása legelején. Írói munkássága szerb nyelven folyt. Erre talán némi magyarázatot adhat az is, hogy Andrić erősen hitt a délszláv népek közös államának eszméjében. Hüségét bizonyítva a ,jugoszlávság" eszméjéhez, többször is határozottan szerbnek vallotta magát, és irodalmi munkásságát a szerb irodalomhoz kötötte. A nagy horvát író, Miroslav Krleža Ivo Andrićot „katolikus szeszélyủ bosnyák elmének” titulálta. ${ }^{1}$ Legtöbb múvének színhelye és témája a hajdani Bosznia, ,a gyúlölet földje”, ahol a megosztottság és a sehová sem tartozás az évszázados egzisztenciális alapélmény. „Súlyosan és biztosan üt a katolikus katedrális órája: éjfél után kettő. Egy percnél több telik el (pontosan hetvenöt másodperc, megszámoltam), és csak akkor jelentkezik valamivel gyengébb, de átható hangon a görögkeleti templom órája; az is a maga éfél utáni két óráját üti el. Kisvártatva rekedt, messziről jövő hangon üt a Bég-mecset melletti torony órája, mégpedig a tizenegyet, a kísérteties török időt, a világ távoli, idegen tájainak különös számítása szerint. A zsidóknak nincsen órájuk, amely elütné az időt, és csak az egy Isten tudja, mennyi az óra most náluk, mennyi a szefárdi, és mennyi az askenázi számítás szerint. Még éjjel is, amíg minden alszik, éjnek éjszakáján is virraszt a puszta órák számításában a különbség, amely elválasztja ezeket az alvó embereket [...]. És ez a különbség hol láthatóan és nyíltan, hol láthatatlanul és alattomosan, de mindig hasonlít a gyúlöletre, és gyakran teljesen azonos is vele".

* TApodi Zsuzsa (1961), dr., irodalomtörténész, a Sapientia EMTE Humántudományok Tanszékének docense. E-mail: tapodizsu@yahoo.com.

1 Idézi Bori Imre: Ivo Andrić. Forum, Újvidék, 1992.12.

2 Ivo Andrić: Djerzelez Ali útja. Idézi Bács ki György: Utószó. Ivo Andrić: Híd a Drinán. Irodalmi, Buk., 1965. 398 (a továbbiakban BÁcsкı: Utószó). 
Az 1945-ös Vezirek és konzulok című regényében írja: „Senki sem tudja, mit jelent két világ peremén születni és élni, egyiket is másikat is megismerni és megérteni, anélkül azonban, hogy valamit is tehetnénk azért, hogy ez a két világ megmagyarázza egymást és közeledjék egymáshoz; szeretni és gyülölni egyiket is, másikat is, egy életen át ingadozni és habozni, két országban élni egyetlen haza nélkül, mindenütt otthon lenni és örökké idegennek maradni; röviden: keresztre feszítve élni, de áldozatként és hóhérként ugyanakkor... Ez a levantei ember sorsa, mert ő az a poussiére humaine, az az emberi porszem, amely kínosan lebeg Kelet és Nyugat között anélkül, hogy bármelyikhez is tartozna, mert mindkettő eltaszítja magától”. ${ }^{3}$

A szerző doktori értekezésének témája is a török hódoltság kora, nem véletlen, hogy a Travniki krónika vagy a Híd a Drinán is ezt a világot idézi. Andrić utolsó regényének címadó hőse önként köteleződik el egy birodalom szolgálatában: a 19. századi valós történelmi személyiség, a renegát Omér pasa a szultáni modernizációs törekvések egyik legkövetkezetesebb végrehajtója volt. Omér szerbnek született, megszökött az osztrák hadseregből, fölvette az iszlám vallást, és mivel roppant tehetséges és becsvágyó volt, szédületes karriert futott be az Oszmán Birodalomban. 1848-49-ben, mikor Havasalföldön volt pasa, ő fegyverezte le a szabadságharc után délre menekülő magyar honvédeket. Abdul Medzsid szultán iskolatársa és barátja volt, s ha valahol lázadás tört ki a birodalomban, ő verte le. A regény a boszniai büntető hadjárat eseményeinek krónikája. 18 fejezetből épül fel: a kezdő és záró rész egyféle keret ( $A$ bevonulás, $A$ kivonulás), közöttük pedig képek sorozata áll - ez emlékeztet a keleti irodalom kedvelt narratív eljárására, melyet megtalálhatunk $A z$ ezeregy éjszaka meséitől Orhan Pamuk A nevem pirosáig - az epizódokban színes vallási és nyelvi kavalkád tárul az olvasó elé.

Mohamedán, tradicionális nézőpont alapján a szultáni modernizációs tervek egyet jelentenek azzal, hogy „gyaurrá akar tenni,” a tervek ellen szegülő boszniai pasák nézőpontjából Omér ugyanolyan renegát, mint a keresztények szerint: „Annyi szent, hogy nincs benne egy szemernyi török vér sem!”. ${ }^{4}$ A bosnyák előkelők számára rémisztő, hogy a szultán megszálló hadseregének tisztjei szőkék, németül, magyarul vagy lengyelül beszélnek, isznak, káromkodnak. Arif bég, a tüzér pasa, aki korábban Zygmunt Ehring névre hallgatott, s akit régóta eltéphetetlen szálak füznek Omér pasához, nagy lakomán látja vendégül tiszttársait. „A szakács a doktor földije, bécsi. [...] A doktor nyugodt énekét rég felváltotta a lengyel táncok ritmusa, ahol a jókedv és féktelenség mélyén érezni a kihúlt könnyeket. A tisztek már felálltak a helyükről. A krakoviákot járják. Mujaga házát nem ilyen vad duhajkodásra építették, a csizmák alatt meghajlik a padló, és tompán recseg. A csárdás, amelyet elragadtatott hévvel táncolt és dallal kísért két magyar, az efféle épület számára elviselhetetlen megterhelést jelent”. ${ }^{5} \mathrm{Az}$ elfogyasztott bor hatására elszabadulnak az elfojtott indulatok. „A beszélgetés párhuzamosan folyik, mondanivalójuk összefonódik, vagy éppen ütközik, gondolataik nem kapcsolódnak egymásba, önmagukban is értelmetlenek. Akik beszélgetnek, azoknak éppen ellenkezőleg az az érzésük, hogy a dolgok logikusan következnek egymásból [...], így válnak hallatlanul bölcs, igaz, harmonikus, gondolatokban gazdag, varázslatos beszélgetésekké, melyek során ezek a komoly és boldogtalan emberek mint a játszó gyerekek hőstetteket hajtanak végre, olyanokká válnak, amilyenek lenni szeretnének, valóra váltják azt,amire gondolnak. S e csodás mesékből

3 Ivo Andrić: Vezirek és konzulok. Idézi BÁcski: Utószó 399.

4 Ivo Andrić: Omér pasa. Ford. Csuka Zoltán. Európa, Bp., 1984. 30.

5 Uo. 73. 
összeálló, háborgó tenger közepette, időnként, mint valami sziget, felmerül egy-egy éles elméjű és hajszálpontos megjegyzés mindennapi emigráns életük felfüggesztett és száműzött valóságából”. ${ }^{6}$

A szereplők szintjén megmutatkozó rendkívüli etnikai-nyelvi színesség ellenére az identitás, az identitásváltás nem válik kifejtett problémává Andrić regényében. Eklatáns példa erre Szaida hanuma, a pasa felesége, leánynevén Ida Defilippis. Az, hogy a rendkívül szép nő férjhezmenetele után beilleszkedik a mohamedán környezetbe, annak tulajdonítható, hogy származása magán viseli egy másik, soknemzetiségű birodalom sorsokat alakító hatását. A dédapja Friuliban született, osztrák császári tisztként ragadt Brassóban, ahol benősült egy szász protestáns családba. A katolikus hitet megtartó, vagyonos és filozofikus hajlamú apa egy szenvedélyes és iszákos magyar nőt vett feleségül. A szülők halála után a bécsi konzervatóriumban tanuló lányt az Onkl Nikiként emlegetett Nicolae Ghica herceg vette pártfogásba, s vitte magával Bukarestbe. „Egész ifjúságában apja képe mint egy vezércsillag lebegett előtte, de ha válaszút elé került, egyszeriben megjelent előtte az anyja, és kérlelhetetlenül kijelölte az útját”. ${ }^{7}$ Mikor az idős pártfogó el akarta csábítani, Ida férjhez menekült Omér pasához. Bár csak a külvilág előtt kellett mohamedán fátylat viselnie, otthon európaiasan öltözhetett, szabadon és biztonságban érezhette magát, az identitásváltás mégsem ment zökkenők nélkül. Hamarosan kiütköztek a gyermekkorában, anyjától látott viselkedési minták: „Már a házasság első esztendeje után Szaida hanuma hirtelen megváltozott. Ezt a változást csak azok vették észre, akik a közelében éltek, mert váratlan és megmagyarázhatatlan volt. Inni kezdett”. ${ }^{8} \mathrm{~A}$ menekülésnek hasonló útját választotta tehát, mint az emigráns katonatisztek.

Akárcsak a Híd a Drinán című regényben, az erőszakos események balladává stilizálódva élnek tovább a közemberek között, mint Costache Nenisanu és a szerb Andja tragikus története, aki a pasa bennfentese helyett a görög Djordjét választja, ezért a románból lett török a nyílt utcán megöli, majd öngyilkos lesz. „Aztán sötétedéskor eltemették őket két különböző sírban, gyászmenet nélkül, beszenteletlen földbe, a temető szélén, ahová a közönséges gyilkosokat és öngyilkosokat temetik. És minden eltűnt, mintha a két vértelen holttesttel a két névtelen sírban minden örökre el lenne temetve. De nyomban az eset után, már másnap az egész ügy újból feltámadt, és új formában, megváltozva, felnagyítva vagy eltorzítva, valósággal alaktalanná, értelmetlenné válva nőttön-nőtt és terjedt az emberek között, de elsősorban a konakban és a városban, azután egész Boszniában és Hercegovinában. Costache szomorú drámájából az ismeretlen lánnyal most mindenki a saját ízlésének, vérmérsékletének megfelelő történetet faragott". ${ }^{9}$ A protezsáltja által elkövetett gyilkosságért Szaida hanuna a megszállás fojtogató politikai viszonyait okolja, a birodalom gyökértelenné tevő folyamatait, és nem is jogtalanul. „Miféle ország ez, amely valamennyiünket felfal? És miféle senkiháziakból és bűnözőkből álló banda gyưlt össze ebben a konakban? Micsoda degenerált alak! Még egy angyalt is megrontanának ezek a naplopó semmirekellők! Mióta ebbe az országba jöttek, még komiszabbak. Ez az egész együttvéve megbabonázta és megbolondította azt a szerencsétlen

6 Uo. 75.

7 Uo. 188.

8 Uo. 189.

9 Uo. 219. 
Antoine-t, úgyhogy teljesen megváltozott, elment az esze. [...] Egy másik országban, másfajta emberek között ezt soha meg nem tette volna" ${ }^{10}$

Milorad Pavić szerb író (1929-2009) belgrádi egyetemi tanárként kezdett posztmodern regényeket írni. A Kazár szótár 1984-ben jelent meg, bonyolult struktúrájú posztmodern alkotás. Műfaji sokszínűséggel büszkélkedhet: van benne családregény (a Brankovićok története), hoffmanni fantasztikus-szürrealista mese az álomvadászokról, történelmi regény a kazárok birodalmáról és a Habsburg-török háborúról, titkokat felfejtő krimi. A szótárforma a tudás tárolásának legökonomikusabb változata, felhasználása az irodalomban nyitott múvet eredményez, melynek célja az olvasó aktív bevonása az értelmezésbe, hiszen már a szócikkek elolvasásának sorrendjét is ő választja, olvashat elölről vagy hátulról, lóugrásban vagy a szócikkek végén található utasításokat követve. Minden fordítás más-más sorrendet eredményez, ám a szerző külön női és külön férfiváltozatot is szerkesztett. Az önálló szövegegységek öszszeillesztése tehát ebben a müben is fontos szerepet kap.

A Kazár szótár nagy népszerüsége, Eco $A$ rózsa neve című regényének sikeréhez hasonlóan, ${ }^{11}$ annak tulajdonítható, hogy minden olvasói réteg talál benne a maga érdeklődésének megfelelőt: krimit, fantasztikumot, szexet vagy nemzetfilozófiát, történelmi és művelődéstörténeti adatokat, és izgalmas, nyitott szerkezetet. A regény témája egy valóságos, de kevéssé ismert nép (a kazárok), és egy valós, ám részleteiben szintén homályos történelmi esemény: a kagán által szervezett 8-9. századi hitvita a három monoteista vallás képviselői között. A forma rendhagyó: három könyvből (vörös - keresztény, sárga - zsidó, zöld - mohamedán) álló szótár. Itt is megjelenik az elveszett és a 17. században rekonstruált kézirat fikciója (a vita keresztény résztvevője Szent Cirill, akinek életrajza és más források is utalnak a kazár küldetésére - itt tehát nem kitalált, hanem valóban elveszett ál-dokumentummal van dolgunk, hasonlóan az Eco könyvében keresett Arisztotelész-kötethez), valamint a mérgezett könyv toposza is. Daubmannus, a Kazár szótár 1691-es kinyomtatója ugyanis egy példányt méreggel itatott át, és mivel az inkvizíció minden könyvet elégetett, csak ez a bizonyos mérgezett nyomdafestékű, arany borítójú, valamint az ezüst fedelű kontrollpéldánya maradt fenn. Ezért írhatja a 20. századi közreadó a könyv elejére a talányos-ironikus, ugyanakkor erőteljes kíváncsisággerjesztő megnyugtatást a mit sem sejtő befogadónak: „E könyv írója kezeskedik olvasója előtt, hogy nem hoz rá halált a könyv elolvasása, miként elődjére, a Kazár szótár 1691. évi kiadásának olvasójára hozott”. ${ }^{12}$ Maga a kinyomtató Johannes Daubmannus (alias Jakób Tam Dávid ben Jahja) egy ortodox szerzetes által tollba mondott szöveget adott ki, melyet a zsidó Cohen, a szerb Branković, a mohamedán Maszúdi és az „álomvadászok” segítségével rekonstruált a szintén elveszett zsidó, keresztény és mohamedán források alapján. Ennek a nyomtatványnak a 20. századi rekonstrukciója (kiegészítve a későbbi ide vonatkozó adatokkal) tehát óhatatlanul három idősíkot vetít egymásra: a legendás kora középkort, a balkáni háborúk szenvedésekkel teli korát, valamint a 20. század végét. A hősök - legyenek bár történelmiek, legendásak vagy a három vallás ördögei - reinkarnálódnak.

10 Uo. 236.

11 Milosevits Péter ,az Eco-féle trükkregény holdudvarába” sorolja. Milosevits Péter: A szerb irodalom története. Tankönyvkiadó, Bp., 1998. 512.

12 Milorad Pavić: Kazár szótár. Ford. Brasnyó István. Cartaphilus, Bp., 2006. 11. 
A krimijelleg és a posztmodern önreflexivitás egy ironikus mondatban ötvöződik a regény első lapjának hátoldalán: „Itt nyugszik az az olvasó, aki soha nem fogja felütni ezt a könyvet. E helyt mindörökre holt". ${ }^{13} \mathrm{~A}$ stílus változatos: a bizánci krónikák cikornyás meseszövése, mohamedán díszítőkedv és $A z$ ezeregy éjszaka meséinek fantáziavilága, ószövetségi és középkori zsidó mesék élményvilága áll egymással szemben, és mutatja fel a különbözőségben is közös vonásokat. Ezeket a 20. századi tudós rekonstruálói szöveg ellenpontozza: a modern szerkesztő pl. egységesítette a 17. századi, Daubmannus által kiadott szótár három könyvének három fajta időszámítását. Az időszámítások különbözésének, az egyidejủ különidejüségnek a problémája tehát, akárcsak folklorizálódás balkánias folyamata, ebben a regényben is megjelenik. Eufrosina Lukarevićnek, Samuel Cohen szerelmének a halála például, a Sárga könyv szerint valahol Erdélyben következett be, ahová a nő követte Dubrovnikból száműzött szerelmét, és története egy 1721-es, Kotorban fennmaradt olasz sirató szerint összekapcsolódott a Drakula-mítosszal.

A mú szerkezete nyitott, ám a regény értelme csak akkor bomlik ki, ha valamilyen úton végigolvastuk a teljes szöveget. Háromszor újrakezdődő betürendben ismétlődnek a szócikkek, melyek részben fedik egymást. Az olvasó választhat, úgy is, hogy könyvenként, vagy az azonos címszavakat egymás után olvasva hatol előre a szövegben. Mivel minden ismétlődő címszó esetében a szerző másképp láttatja az eseményeket, az olvasói értelmezés csak tévelyeghet a különböző variánsok között, eldönthetetlen, hogy melyik változat tartalmazza az igazat.

Világossá válik a verziók egybevetéséből az a posztmodern történetírásban is evidenciaként kezelt felismerés, hogy mindenki a saját szempontja és érdeke szerint magyarázza a történelmet. (Ateh hercegnő a keresztény forrás szerint rábírta a kagánt, hogy őt követve kereszténnyé váljon népével együtt, a zsidó forrás szerint a zsidó hit felvételére buzdította eredményesen az uralkodót, a mohamedán szerint viszont döntő szerepe volt a kazárok mohamedánná válásában.) Szociálpszichológiai tény, hogy a kollektív identitás legstabilabb öszszetevője a vallási! Ugyanakkor, a regény végén található, 20. századi gyilkosságok túlélője a zsidó kutatónő - ez a mozzanat, burkoltan ugyan, de felfedi a történelmi valóságot: a kazárok a megidézett vita nyomán a mózesi hit követóivé váltak.

A regény könyveiben ismétlődő arc, álom, tükör stb. motívumok a hálós szöveglabirintus láncszemei. Az identitás is labirintusszerűvé, átláthatatlanná válik. Branković halálában megéli saját őseinek és leszármazottainak a halálát.

A posztmodern irodalom által kedvelt önreflexivitás ironikus, olvasót fricskázó sziporkái lépten-nyomon megfigyelhetők Pavić könyvében. Ilyenek a tudós 20. századi közreadó „használati utasításai”, a labirintusjelleg felfedése: „A szótár olvasóját ne bátortalanítsák el ezek a részletes utasítások! [...] Megtörténhet ugyan, hogy eltévedt e könyv szavai között, ahogyan Maszúdi, e szótár szerzőinek egyike tévedt el az idegen álmokban, és sohasem találta meg a visszautat. Ebben az esetben nem marad más hátra számára, mint hogy a kellős közepéból bármely irányba elindulva törjön utat magának" ${ }^{14} \mathrm{Az}$ irodalomelméletet oktató szerző néha kiszól a szövegből: „Így mindegyik olvasó maga kerekítheti ki a saját könyvét, akár egy dominó- vagy kártyajátszmát, és ettốl a szótártól annyit fog kapni, mint a tükörtől, vagyis amennyit

13 Uo. 2.

14 Uo. 19. 
beletesz, mivel az igazságtól - ahogy e lexikon egy lapján áll - nem is nyerhető több, mint amennyit adunk neki”. ${ }^{15}$ Igazi szemiotikai játékra hívja tehát fel a nyomolvasó olvasót: „mert csak az teremtheti újra a világot, aki a helyes sorrendben tudja e könyv részeit elolvasni”. ${ }^{16}$

Mivel a rekonstruált 17. századi szótár szerkesztője nem használ forráskritikát, a stílus pedig mesésen legendás, a 20. századi közreadó látszólag precíz kommentárjai is fikcióként hatnak, az olvasó teljes bizonytalanságban van afelől, hogy mi a fiktív és mi a „valóságos” történelmi tény az olvasottakból. Nemcsak a szerkezet labirintusszerű, a megidézett valóság is az. A különböző történelmi síkok közötti átjárásból szintén egy időben épülő rejtélysor körvonalazódik. Ehhez járul a hősök identitásának megsokszorozódása, amelyet tematikus motívumként a „kazár arc” testesít meg. Az arc, a lélek tükre itt egyértelműen a kiismerhetetlenség, a titok motívumával együtt jelenik meg a kazárok örökre megfejthetetlen sorsának emblémájaként. A kazár arc motívuma felbukkan a regény végén szereplő 20. századi gyilkosságokban is, melyeknek a kazár iratok megszerzése az indítéka. A gyilkosok a három túlvilág reinkarnálódott képviselői, akik azt akadályozzák meg, hogy Ádám Ruháni, azaz a Kazár szótárban megnyilvánuló eredendő teljesség reinkarnálódhasson a három monoteista vallás képviselőinek összehangolt kutatása révén: tehát a posztmodern széttöredezettség állapotát kívánják fenntartani. A teljesség, tökéletesség egyszerre transzcendens és mitikus, ám csupán nyelvi formában, a Kazár szótár által hozzáférhető. Ez a posztmodern nyelvfilozófia ama kiemelt kérdésére utal, hogy létezik-e valóság a nyelven kívül, illetve, hogy csakis a nyelv révén vagyunk képesek érzékelni a valóságot.

A mitikus szereplők újjáéledésének játéka részben elfedi, de a befogadóban fel is kelti a gyanút a Kazár szótár 20. századi tudós közreadója iránt, ugyanis a kérdéssel foglalkozó mohamedán arab és szerb keresztény szakembert Isztambulban megölik, illetve a zsidó származású Dorota Schultzot hamis vád alapján börtönbe csukják. Kihez kerültek a szállodában maradt kéziratok és a Daubmannus-féle őskiadás egyetlen megmaradt, nem mérgező példánya? Logikus, hogy csakis magához a többszörös gyilkoshoz. (Ha Schultz asszony másik, krakkói énje a közreadó, az értelmezői út visszavezet az identitások útvesztőjébe.)

Dr. Isajlo Suk, az Újvidéki Egyetem tanára is eltéved a kettős (épület = könyv) labirintusban: „[...] el-elvéti az utat a pompás épület körkörös folyosóin, e kerengőkön, amelyeken örökre szem elől téveszti az ember a kiindulópontot. Ez az épület néhanapján valami ismeretlen, általa még el nem sajátított nyelvü könyvre emlékeztette: a folyosók az idegen nyelv mondatai, a szobák pedig sosem hallott idegen szavak". ${ }^{17}$

Bármennyire mesésen szürreálisak is a történetek, a befogadóban felkeltenek bizonyos referenciakényszert. Közép-Kelet-Európa diktatúrákat megtapasztalt olvasója ráismerően bólogat, amikor például arról olvas, hogy az Újvidéki Egyetem tudós archeológusát a saját diákja vizsgáztathatja, vegzálhatja, betiltják a művét, vagy ismeretlenek ok nélkül felpofozzák az utcán. Az arra érzékeny olvasó a regény megjelenésekor megérezhette: a Jugoszlávia nevű politikai képződmény menthetetlenül felbomlásra van ítélve, hiszen a nagy, többnemzetiségú Osztrák-Magyar Monarchia és Ottomán Birodalom utódjaként maga is többnemzetiségű,

15 Uo. 20.

16 Uo. 18.

17 Uo. 87. 
többkultúrájú ország volt, amelyiknek nem sikerült integrálnia a szétfeszítő ellentétes törekvéseket.

Jože Hradil (1935) szlovén író, műfordító Képek arc nélkül (Slike brez obrazov) című családregénye, mely Mariborban jelent meg 2012-ben, a realista prózapoétikát követi. Ez a realizmus azonban a 21. századé: a nagytörténetek mellett legalább olyan fontosak a mikrotörténetek, a külső események és a belső változások egymást determinálják.

Emlékezés és felejtés, identitásőrzés és spontán vagy erőszakos asszimiláció, tolerancia és mindenféle kirekesztő politika okozta emberi torzulások kavalkádja jelenítődik meg a regényben. Az emlékek mintegy száz évet fognak át: a 19. század végéig nyúlnak vissza. A cselekmény a magát Jurijnak nevező narrátor gyermekkorában, a második világháború elején indul, és a jelenig tart. Családregény, memoár, Bildungsroman ismérvei keverednek a szövegben.

Thomka Beáta paradigmatikus megállapítása szerint: „a társadalmi mikroközösségek, etnikai csoportok és tagjaik történelmi tapasztalatának és identitásának gyakori meghatározója a határhelyzet. Ehhez azonban nem kell feltétlenül sem valamely határszélen élni, sem határátlépőnek lenni, hisz a történelem anélkül rendezi át európai határait, hogy az adott térségben élő nemzedékek bármikor elhagyták volna szülőhelyüket, ahogyan ez a 20. században többször is lejátszódott”. ${ }^{18}$ Jože Hradil önéletrajzi fogantatású regényének elsődleges helyszíne az író szülővárosa, Muraszombat, mely a regénycselekmény száz éve alatt öt ország: az OsztrákMagyar Monarchia, a Szerb-Horvát-Szlovén Királyság, Magyarország, Jugoszlávia és Szlovénia része volt.

A 20. század során az itt élők (Kelet-Európa hasonló sorsú népeivel együtt) megtapasztalhatták két szélsőséges totalitárius rendszer és mindenféle nacionalizmus emberpusztító hatását. (A szerzői önportré-hős apját majdnem agyonlövik az első világháború után, mert társaival szlovén népdalt énekel; a család két kisebb gyermekét felnőttkorig kínozza a víz hátán úszó hulláknak a képe, a nagyfiút pedig az az emlék, hogy a sebesülteket szállító teherautó retesze elmozdul, és a kigördülő, magatehetetlen embereket elgázolja a hátul jövő sebesültszállító.)

A retrospektív narrációban a visszapillantás pozíciója az uralkodó. A cselekményt a regény első részében a gyermek nézőpontjához közelítő narrátor meséli. A második rész narrátora ugyanaz a személy, az immár tudatos felnőttként családtagjaira visszatekintő Jurij. Az egyetlen individuumon átszűrt kollektív tapasztalatot érzékelteti az az eljárás, hogy nincsenek hagyományosan jelölt párbeszédek, mindig az éppen soron következő emlékező szövegébe illeszkednek dőlt betűkkel a beidézett egyéb szereplői szólamok. Így gyakran három-négy narrátor szövege épül egymásra. A következő részben ezek: az implicit szerző, Jurij, Stanko, Király. A Dachauból szabadult unokatestvér előbb felvételét kéri a kommunista pártba, majd kilép belőle. Jurij az okokat firtatja. „Stanko nem válaszolt egyenesen a kérdésére, Királyról kezdett beszélni, akivel Dachauban barátkozott össze.

Vele beszélgettem a legszívesebben, különösen később, amikor hazajöttünk. Egyszerû ember volt, de sok minden járt a fejében, csupa bölcs gondolat. Munkáját lelkiismeretesen végezte, mert szerette. Elmondta nekem,

18 Tномка Beáta: Déli témák. zEtna, Zenta, 2009.7. 
hogy nem sokkal szabadulása után többször is más munkát kínáltak fel neki, de ő visszautasította. Érezte, hogy valami hitványságról van szó.

Tudtam, mire megy ki a játék, mesélte Király, borotva és pamacs helyett ceruzát adtak volna a kezembe, s hozzá valami funkciót, és akkor válogathatnék az emberek között, fehérre és vörösre oszthatnám őket. De én a szemükbe mondtam, hogy csak azt szeretem csinálni, amihez értek, az én kezembe olló és pamacs való, és nekik is azt ajánlom, hogy eredjen inkább kapálni, aki a háború előtt paraszt volt, és menjen vissza az ólba, aki korábban disznókat nevelt. Azt pedig gondolni se merészeljék, hogy az orvoson kívül bárki is turkálhat az emberekben, különösen, ha az illető korábban a trágyában turkált". ${ }^{19}$

A kizárólagosságok elleni határozott szerzői fellépés a gyerekkort megidéző részben abban érhető tetten, hogy a gyermeknek a sztereotípiákat reflexió nélkül átvevő álláspontja megkérdőjeleződik: Jurij mindent elhisz, amit az újságok írnak, de mellette áll barátja, Bagi, aki mindig egy másik lehetőség mellett kardoskodik. A két fiú egymás ellentéte. Jurij magyar apja a grófnő intézője, ők gazdagok. Bagi szülei szegény szlovénok, akik soha nem csókolnának kezet Zichy grófnőnek. Jurij a németekért rajong, a zsidókat ellenségnek tekinti, barátja viszont felvilágosítja, hogy a fiút teniszezni tanító, Farkas nevü állatorvos is zsidó. Bagi a szovjet hadseregnek szurkol, pánszláv álmokat melenget, ám - a gyermeki ártatlanság bizonyítékaként- mindezek az ellentmondások nem árnyékolják be kettőjük barátságát. Mintha példázatot olvasnánk arról, hogy az ellentétes szimpátiáknak nem kell megrontaniuk az egymás szomszédságában élők barátságát. A 6-10 éves gyermek eszmélkedő tudata ütközőpontja a mesterségesen létrehozott, kollektív identitásnak, amely sokszor ellentéte a mikroidentitásnak, a család és az egyének önértelmezésének. A kisiskolás Jurijt gyermekkori szimpátia fúzi például a magyar csendőr lányához, annak ellenére, hogy a lány apjának erôszakossága nagyon taszítja. Mégis fáj neki, amikor a család elmenekül az oroszok elől: „Amikor Jurij rájött, amikor egyértelműen megállapította, hogy a szekér Évával végleg eltűnt, arcát a tenyerébe temette, és azon gondolkozott, hogy most összeszedi bátorságát, és hanyatthomlok a szekér után ered. És arcába vágja a csendőrnek, amit már százszor végiggondolt, a szemére vet mindent, igen, most utánuk rohan, most mindjárt, és megmondja neki, az arcába üvölti, hogy emlékezzen csak vissza, hogy pattogott, hogy vitézkedett a csendőrei elött, hogy ők milyen könyörtelen fölénnyel hajtják majd vissza az oroszokat az ólukba. Mert Hitler ujja már a ravaszon van, és a csodafegyvere, a fau három, egy perc alatt végez az orosz hadsereggel. Akkor most miért menekül?”. ${ }^{20}$

A nosztalgia nem csupán a bimbózó érzelmeknek, a kultúrfölény elveszített illúziójának is szól. „Az orosz hadsereg egy nagy nulla, drága Éva, így mondta az apád. Ugye emlékszel, mindig és mindenütt ezt mondta, egészen tegnapelóttig. Emlékezz vissza, milyen szép volt, amikor megérkeztetek Belatincba, nem ám szekéren, hanem csodaszép, fényes autóban, amely akkor, négy éve,

19 Jože Hradil: Képek arc nélkül. Ford. Körtvélyessi Klára. Európa, Bp., 2013. 234.

20 Uo. 107. 
pontosan a Rituper vendéglöje elött állt meg, ahol most én állok, itt, ezen a helyen, abol még most is látlak - olyannak, amilyennek szeretlek. Mondd, hogy vége a rossz álomnak...". ${ }^{21}$

A regény első része a háború végéig, az új társadalmi rend meghonosításáig követi az eseményeket, s a gyermek Jurij fokozatos érlelődését, gondolkodásának árnyaltabbá válását kíséri nyomon. Az ideológiák megszabta szembenállások világában nagyon nehéz az emberség megőrzése. Az apa sorsa ugyanúgy példázatossá válik, mint a nagyfiúé, Vladimiré. (A magyar apa az első világháború után önként marad szlovén menyasszonya hazájában; amikor viszont a Muravidéket Magyarországhoz csatolják, szlovén egyetemi tanárt bújtat; amikor a szovjet csapatok átvonulása után átveszik az uralmat a Tito partizánjai, magyarsága miatt bebörtönzik. Jurij mindenben utánzott bátyja, Vladimir szláv nevet visel, lázadó fiatalemberként beáll önkéntesnek a magyar hadseregbe; a szovjet fronton megsebesül, fogságba esik, átáll a szovjetek oldalára, velük érkezik haza; de az otthon maradt jugoszláv partizánok ellehetetlenítik a helyzetét, ezért átszökik Ausztriába.)

A felnőtt Jurijt anyja magyarrá asszimilálódott nénjeinek sorsa is érdekli. Befogadás és kirekesztés folyamatai, az önkéntes és kényszerű asszimiláció kérdései személyes sorsokban figyelhetők meg. (Szülei és Muraszombatban maradt, Ilka nevű nővére nem azért tagadják meg Paulát, mert a fôvárosba került nő Budapesten nyelvet váltott, hanem azért, mert zsidó férfihez ment feleségül.) „Ahogy Jurij apja Szlovéniában, úgy anyja rokonai Magyarországon új körülmények közé, új nyelvi és szellemi környezetbe kerültek, egy olvasztótégelybe, amelyben volt, amit átvettek, mást meg feladtak, akár a hétköznapi szokásaikról, akár a nyelvükről volt szó, de megváltoztatták a nevüket, sőt a vallásukat is. A Hradil név, a jellegzetes cseh -il végződéssel a szláv környezetben, a szerbek, a horvátok és szlovénok újonnan alakult országában természetesen nem okozott gondot, ugyanez a név viszont Magyarországon zavaró volt, ezért néhányan az apja testvérei közül inkább Hragyilra magyarosították. Akik úgy érezték, hogy a magyar társadalmi-politikai környezetnek, a magyar nyelv szellemének ez sem felel meg, radikálisabb megoldást választottak, és Balsaira, sőt Hegyaljaira meg Hargitaira változtatták a nevüket. A Murántúlról érkezett három nő vitathatatlanul szláv neve ebből a szempontból nem okozott nehézséget, a két Markovics nővér, mihelyt férjhez ment, a magyar párja nevét viselte [...]. ${ }^{22}$ Paula, miután szembekerül családjával, tudatosan vált nyelvet. „Én meg összeszoritottam a fogam, és mindent elkövettem, hogy eltüntessem az új környezetembe nem illö nyomokat. [...] Tisztában voltam vele, hogy nem lesz könnyú megbirkózni a nyelvvel, ezért mindenben engedelmeskedtem szigorú tanáromnak, és egy idó múlva már magyarul gondolkoztam. Tanult nyelvem folyamatosan gazdagodott, anyanyelvem egyre jobban kopott. Azt is megfogadtam, keményen elhatároztam, hogy nem beszélek többet szlovénül. "'3 A kényszerüségből vállalt önfeladás azonban lelki sérülést okoz. Évek múlva így emlékszik erre Paula: „Megtagadtam a származásomat, a gyökereimet. A helyzetem, a körülményeim miatt rejtegetnem kellett igazi arcomat. Mind a pestiek, mind a muraszombatiak elótt”. ${ }^{24}$ Paradox módon, Paula lánya, Gizella magyar „anyanyelv-"éhez ragaszkodik mindenekfölött, miután kivándorol Magyarországról. Számára az okoz szenvedést, hogy le kell mondania a magyar nyelvről, kultúráról. Gizella Kanadába

\footnotetext{
21 Uo. 108.

22 Uo. 298-299.

23 Uo. 355.

24 Uo. 359.
} 
emigrált, Judit nevü lánya ugyanolyan tudatosan szakít a szülőföldjével és anyanyelvével, mint annak idején a nagyanyja tette.

Jurij unokatestvéréhez, Gizellához kapcsolódik az arc nélküli fénykép, az identitás elvesztésének metaforája, amely a cím mellett a könyvborítón is megjelenik. Gizi anyja Paula, a szlovén anyanyelvű katolikus nő, apja magyar anyanyelvü zsidó férfi. Ő magyar katolikus, férje magyar anyanyelvű zsidó. Lánya magyar katolikus, aki szintén magyar zsidó férfihez megy feleségül, s együtt emigrálnak Kanadába. A hozzájuk költözött kilencvenéves Gizellát arra biztatják, hogy tanuljon angolul, cseréljen nyelvet. „Gizi egyszer tréfásan megjegyezte, hogy övéi, ha tehetnék, legszívesebben seprűvel kergetnék az angol szótárhoz, pedig tudják, hogy hiába. Tisztában vannak vele, mi a helyzet nálam: bármilyen gyorsan tanulok meg egy-egy szót, az elózót közben elfelejtem, így aztán mindig csak egy szavam marad". ${ }^{25}$ Halála előtt az elmagányosodott, gyökereitől elszakított asszony kivágja a fényképekről az elvesztett családtagok arcát.

A könyv legemlékezetesebb a metaforája pozitív töltetű: a kézfogások lánca Barabási Albert-László ${ }^{26}$ hálózatelméletének szép, humánus, a megbékélést kifejező jelképvariációja. A metafora groteszk-mulatságos változata szerint kitalálója, Józsi bácsi, Paula férje kamaszkorában szerelmes volt a királynőbe, Sissibe. Két barátjával 20 kilométert gyalogolt, hogy megleshesse Ferenc József császár feleségét a gödöllői kastélyban. Amikor észrevették és elkergették őket, Józsi könyörgött, hogy őt is pofozzák fel: az inas, aki őt megütötte, biztosan hozzáért már a királyné kezéhez, s így, áttételesen, Józsi is érintkezésbe került az imádott lénnyel. A kézfogás-metafora didaktikus, felemelő változata szerint Józsi bácsi egyik dúsgazdag amerikai ismerőse egyszer egy nagy összeget adott egy kolduló gyermeknek, aki hálából mindenütt a nyomában járt. A kórházba is elkísérte, amikor a gazdag ember balesetet szenvedett, és megmentette az életét, mert pont olyan vércsoportba tartozott, amilyenre jótevőjének szüksége volt. A képletes, időn átívelő kézfogások közvetítőjeként Józsi bácsi átadhatta az íróvá lett Jurijnak Jókai Mór üdvözletét is: „[...] az én kezem által olyasvalakinek a jobbját érintetted meg, aki a legnagyobb magyar mestermüveket irta. Vagyis a sok-sok kézfogás révén te, Jurij, bizonyos értelemben megérintetted a magyar irodalom egyik legnagyobb klasszikusának a kezét". ${ }^{27}$

Ivo Andrić sokszínű vallási-etnikai tablót fest, ám a regényében az identitásváltás nem válik kifejtett problémává, a vallás- és nyelvváltásban a hatalmi hierarchiában való előrejutás motivál, Pavićnál a labirintusjelleg, az átláthatatlanság uralja az identitást is, a harmónia pedig örökre visszaállithatatlannak bizonyul. Hradil regényében a problematizálás kap fő szerepet. Ugyanakkor a szlovén szerző jut el a leginkább emberséges, megbékélést hirdető magatartás hiteles bemutatásáig.

25 Uo. 396.

26 Barabási Albert-László: Behálózva. A hálózatok új tudománya. Helikon, 2008. (Linked, published by Plume, a member of Penguin Group (USA) Inc. 2003.)

27 Hradil: i.m. 378. 
THE BUILDING OF IDENTITY IN THREE SOUTH SLAVIC NOVELS

(IVO ANDRIĆ: OMAR PASHA LATAS, MILORAD PAVIĆ: KHAZAR DICTIONARY, JOŽE HRADIL: PICTURES - WITHOUT FACES)

\section{Keywords: South Slavic literature, empires, borders, multiculturalism, identity}

Ivo Andrić gives a diverse religious and ethnic tablea, but the change of identity in his work does not become a problem set, the religious and language shift is motivated by the advancement in the hierarchy of power, while in Pavićs novel the problem of identity is dominated by a labyrinthine nature and opacity, harmony proves to be lost forever. In Hradil's novel problematization gets the upper hand. However, it is the Slovenian author who succeeds to show the most humane behaviour, leading to true reconciliation.

\section{CONSTRUIREA IDENTITĂŢII ÎN TREI ROMANE SLAVE (IVO ANDRIĆ: OMAR PASHA LATAS, MILORAD PAVIĆ: DICŢIONARUL KHAZAR, JOŽE HRADIL: FOTOGRAFII - F $\breve{A R A ~ F E T ̧ E) ~}$}

\section{Cuvinte-cheie: literatură slavă, imperii, graniţe, multiculturalitate, identitate}

Ivo Andrić prezintă în romanul său istoric un tablou multicolor din punct de vedere etnic şi religios. Schimbarea identităţii motivată de arivism social şi politic nu apare la el ca o problemă primordială. În romanul postmodern al lui Milorad Pavić personajele capătă caracter-labirint, identitatea lor devine de nedescifrat, iar armonia dispare pentru totdeauna. În romanul lui Jože Hradil construirea identităţii capătă accent deosebit. Totodată autorul din Slovenia reuşeşte să transmită un mesaj profund uman, înţelept şi împăciuitor. 